\title{
The role of macrophages in the induction of murine immune response to Actinobacillus actinomycetemcomitans
}

\author{
WIHASKORO SOSROSENO*† and ENDANG HERMINAJENG $\ddagger$ \\ * Department of Oral Biology, School of Dental Science, Universiti Sains Malaysia, 16150 Kota Bharu, \\ Kelantan, Malaysia and Departments of †Oral Biology and $₫$ Oral Medicine, Faculty of Dentistry, Gadjah Mada \\ University, Yogyakarta 55281, Indonesia
}

\begin{abstract}
The aim of this study was to determine the role of macrophages in the Actinobacillus actinomycetemcomitans-induced murine immune response. BALB/c mice were given carrageenan solution by intraperitoneal injection before immunisation with heat-killed A. actinomycetemcomitans. Mice immunised with antigens and phosphate-buffered saline served as positive and negative controls, respectively. One week after the last immunisation, the delayed-type hypersensitivity (DTH) response was assessed by measurement of footpad swelling. Serum IgG and IgM anti-A. actinomycetemcomitans antibody levels and culture supernate levels of interferon (IFN)- $\gamma$ were determined by ELISA. The diameter of abscess formation was determined every 5 days. Shamimmunised spleen cells were transferred to carrageenan-untreated recipients (groups A and $B$ ) and to carrageenan-treated recipients (group D). Antigen-immunised spleen cells were transferred to carrageenan-untreated (group C) and carrageenan-treated (group E) recipients. The carrageenan-treated recipients in groups $F$ and $G$ received macrophages from antigen- and sham-immunised mice respectively. All mice except those in group A were immunised with antigen $24 \mathrm{~h}$ after cell transfer. After 1 week, a partial suppression of DTH response, reduced levels of IFN- $\gamma$, serum IgG and IgM anti-A. actinomycetemcomitans antibodies and delayed healing were seen in carrageenan-treated mice when compared with the positive control. The immune response to $A$. actinomycetemcomitans in groups A, B and D was lower than that in groups $C$ and $E$. Healing of the lesion in the former groups was also delayed when compared with the latter groups. The immune response and the healing of the lesion could be partially restored in carrageenan-treated mice that received antigen-pulsed macrophages (group F) but not in those that received naïve macrophages (group G). These results suggest that macrophages play a partial role in the induction of the murine immune response to $A$. actinomycetemcomitans.
\end{abstract}

\section{Introduction}

Actinobacillus actinomycetemcomitans is a gramnegative bacterium that is regarded as a member of the microflora of dental plaque and, therefore, may play a role in chronic inflammatory periodontal disease (CIPD) $[1,2]$. Evidence has shown that the numbers of this micro-organism are increased in patients with periodontal disease, especially those with early-onset periodontitis [3-6]. Human monocytes and polymor-

Received 31 May 2001; revised version received 11 November 2001; accepted 2 January 2002.

Corresponding author: Dr W. Sosroseno (e-mail:wihaskoro @kb.usm.my). phonuclear neutrophils stimulated with this potential periodontopathogen have been shown to release proinflammatory cytokines, such as interleukin (IL)-1, IL6 , IL-8 and tumour necrosis factor (TNF- $\alpha$ ) [7, 8]. $A$. actinomycetemcomitans has been shown to induce alveolar bone destruction in animal models [9]. It has also been documented that internalisation of this bacterium by macrophages and epithelial cells induces apoptosis $[10,11]$, suggesting that $A$. actinomycetemcomitans may accelerate gingival cell death and thus promote gingival tissue destruction.

It has been shown that macrophages in the gingival epithelial surface beneath periodontal pockets engulf Porphyromonas gingivalis in situ [12]. P. gingivalis- 
induced phagocytic activity by murine macrophages has been found to be enhanced by interferon (IFN) $-\gamma$, but not IL-4 and IL-10 [13]. However, it would appear that gingival macrophages may function primarily as antigen-presenting cells (APCs) [14-16]. Increased major histocompatibility complex (MHC) class II molecule expression on gingival macrophages in patients with periodontal disease would support this assumption $[17,18]$. Suppressed antibody production by macrophage-depleted peripheral blood mononuclear cells highlights the important role of macrophages in the immune response to periodontopathogens [19]. In vitro, human monocytes and macrophages stimulated with antigens from periodontopathogens produce substantial amounts of cytokines, such as IL-6, necessary for antibody production [7]. Therefore, previous studies have indicated that monocytes and macrophages may play a crucial role in both innate and adaptive immunity to periodontopathogens. However, the exact role of macrophages in vivo during the induction of the immune response to periodontopathogens remains unclear. It has been shown that intraperitoneal (i.p.) injection of carrageenan blocks macrophage function in mice [2024] and this may be used to study the immune response. The aim of the present study was to determine the role of macrophages in vivo in the immune response to $A$. actinomycetemcomitans in carrageenan-treated mice.

\section{Materials and methods}

\section{Bacterial and antigen preparation}

A. actinomycetemcomitans Y4 (serotype b), provided by Professor G. J. Seymour (Brisbane, Australia), was cultured under anaerobic conditions in Todd-Hewitt broth supplemented with yeast extract (Difco) $1 \% \mathrm{w} / \mathrm{v}$ as described previously [25]. At maximal growth, bacteria were harvested and washed three times in sterile phosphate-buffered saline (PBS). Purity was checked by Gram's stain. Heat-killed A. actinomycetemcomitans was prepared by heating $50 \mathrm{ml}$ of bacteria suspension at $105^{\circ} \mathrm{C}$ for $5 \mathrm{~min}$. Protein concentration was determined with a commercial protein kit according to the manufacturer's instructions (BioRad, Richmond, CA, USA).

\section{Carrageeenan preparation and injections}

Type 1 carrageenan (Sigma; $5 \mathrm{mg}$ ) was dissolved in $200 \mu \mathrm{l}$ of boiled PBS in an Eppendorf tube, immediately vortex mixed and stored at $4^{\circ} \mathrm{C}$ until used. For the carrageenan-treated groups, three-to-five animals were each given $200 \mu \mathrm{l}$ of carrageenan solution by i.p. injection 5 days and 2 days before immunisation with antigen [26].

\section{Immunisation procedures}

Female BALB/c mice (6-8 weeks old) were divided into three groups, each consisting of three-to-five mice.
Mice in groups I and II were inoculated i.p. with $200 \mu 1$ of PBS 5 days and 2 days before immunisation. On the same day, mice in group III were inoculated with carrageenan solution $(5 \mathrm{mg}$ in $200 \mu \mathrm{l})$. At day 0 , mice in groups II and III were immunised i.p. with antigen suspension $(100 \mu \mathrm{g}$ in $100 \mu \mathrm{l})$, followed by a similar immunisation 1 week later. Mice in group I were sham immunised with $100 \mu \mathrm{l}$ of PBS only.

\section{Assessment of delayed-type hypersensitivity}

Delayed-type hypersensitivity (DTH) response was assessed as described previously [27]. One week after the final immunisation, the right footpad of the mouse was inoculated intradermally with $5 \mu \mathrm{l}$ of antigen solution $(5 \mu \mathrm{g} / \mathrm{ml})$ with a Hamilton syringe. The left footpad was inoculated with $5 \mu$ l of PBS to serve as a control. Footpad swelling was determined with a dial micrometer (Mitutoyo, Japan) immediately before and $24 \mathrm{~h}$ after inoculation. DTH response was calculated by the difference in footpad measurement before and after inoculation.

\section{ELISA for serum antigen-specific antibodies}

One week after immunisation, all mice were killed by $\mathrm{CO}_{2}$ asphyxiation and blood was obtained by cardiac puncture. Serum was then separated and stored at $-20^{\circ} \mathrm{C}$ until used. Serum antibodies against heat-killed A. actinomycetemcomitans were assayed by ELISA as described previously [28]. Briefly, 96-well high-binding plates (Maxisorb Immunoplates, Nunc, Roskilde, Denmark) were coated with $50 \mu \mathrm{l}$ of antigen suspension (heat-killed $A$. actinomycetemcomitans $0.2 \mu \mathrm{g} / \mathrm{ml}$ in $100 \mathrm{mM}$ carbonate buffer). After overnight incubation at $4^{\circ} \mathrm{C}$, non-specific sites were blocked with dried milk $1 \%$ in PBS-Tween 20 (0.05\%). After washing, $100 \mu \mathrm{l}$ of serum diluted 1 in 1000 in PBS-Tween 20 containing dried milk $0.1 \%$ (PBS-T) were added before incubation for $1 \mathrm{~h}$ at room temperature. Antigenspecific $\operatorname{IgG}$ and $\operatorname{IgM}$ antibodies were determined by adding $100 \mu \mathrm{l}$ of biotin-conjugated goat anti-mouse IgG and IgM (Sigma). All antibodies were diluted 1 in 5000 in PBS-T. After incubation for $1 \mathrm{~h}$ and washing, $100 \mu \mathrm{l}$ of diluted streptavidin horseradish peroxidase (1 in 10000) (Sigma) were added and incubated for $30 \mathrm{~min}$ followed by TMB substrate (Sigma) as described by the manufacturer. After incubation for $10 \mathrm{~min}$, the colour reaction was stopped by adding $\mathrm{HCl}$ and absorbance at $450 \mathrm{~nm}$ was measured with a Titertek Multiscan MCC 340 (Lab System, Finland). Pooled serum, derived from heat-killed A. actinomycetemcomitans-immunised mice, was used as positive control and PBS was used as negative control on each plate. Results were expressed as ELISA units, which were calculated by dividing the optical density of the sample by that of the positive control and multiplication by 100 [28]. 


\section{IFN- $\gamma$ levels}

One week after the last immunisation, mice were killed by $\mathrm{CO}_{2}$ asphyxiation and spleens were excised aseptically. A cell suspension was obtained by mincing the spleen on a sterile wire mesh in RPMI 1640 medium supplemented with fetal calf serum $1 \%$, glutamine $1 \%$ and penicillin-streptomycin solution $1 \%$. All the materials for cell culture were obtained from Sigma. After three washes, viable cells were counted and a single cell suspension was obtained. A $200-\mu 1$ volume of cell suspension $\left(2 \times 10^{5}\right.$ cells $)$ was cultured in each well of 96-well plates (Nunc) and stimulated with $0.1,1$ or $10 \mu \mathrm{g}$ of antigen. Unstimulated cell cultures were used as internal controls. Cultures were incubated for 4 days in a humidified incubator with $\mathrm{CO}_{2} 5 \%$ in air. Supernates were harvested and the levels of IFN- $\gamma$ were determined with an ELISA kit according to the manufacturer's instructions (R\&D Systems, Minneapolis, MN, USA).

\section{Primary lesion}

Abscess formation was induced as described previously [28]. Briefly, 1 week after the final immunisation, mice were inoculated with live $A$. actinomycetemcomitans organisms $\left(1 \times 10^{11}\right.$ in $200 \mu \mathrm{l}$ of sterile saline $)$ at two sites on the shaved dorsal surface of the abdomen, $c$. $1 \mathrm{~cm}$ on each side of the midline. The mice were examined daily for 30 days for the presence of lesions at the site of injection. The diameter of the lesion, as measured with a dial caliper (Mitutoyo), was determined every 5 days.

\section{Adoptive transfers}

$\mathrm{BALB} / \mathrm{c}$ donor mice were divided into sham-immunised and antigen-immunised animals as described above. One week after the final immunisation, mice were killed by $\mathrm{CO}_{2}$ asphyxiation and spleens were obtained aseptically. Spleen cells were isolated as described above and $1 \times 10^{6}$ cells in $100 \mu \mathrm{l}$ of sterile PBS were adoptively transferred into recipient mice via the lateral vein of the tail base. The recipient animals were divided into seven groups, each consisting of three-to-five mice. Groups A and $\mathrm{B}$, carrageenan-untreated mice, received spleen cells from the sham-immunised donor animals. Group C, carrageenan-untreated mice, received antigen-immunised spleen cells. Groups D and E, carrageenan-treated mice, received spleen cells from the sham-immunised and antigen-immunised donor animals, respectively. To determine whether exogenous macrophages enhance the immune response to heat-killed $A$. actinomycetemcomitans, antigen-immunised or sham-immunised mice were killed by $\mathrm{CO}_{2}$ asphyxiation and spleens were obtained. A 10-ml volume of cell suspension was then incubated in polystyrene petri plates for $1 \mathrm{~h}$ at room temperature. Culture supernates containing non-adherent cells were carefully aspirated and the adherent cells were harvested with the rubber-end of the syringe stick. After three washes, viable cells were counted and cell morphology was determined by Giemsa and non-specific esterase stain. These plastic-adherent cells were also assessed for their ability to ingest A. actinomycetemcomitans as compared with a murine macrophage cell line [13]. It was found that $>99 \%$ of the plastic-adherent cells were macrophages (data not shown). A $100-\mu 1$ volume of sterile PBS containing $1 \times 10^{6}$ splenic macrophages of the antigen-immunised mice was transferred to carrageenan-treated recipients (group F). Group G, carrageenan-treated animals, received splenic macrophages from the sham-immunised mice. All mice apart from those in group A were immunised i.p. with antigen solution $(100 \mu \mathrm{g}$ in $100 \mu \mathrm{l}) 24 \mathrm{~h}$ after adoptive transfer. Mice in group A were sham-immunised only. DTH response, serum antibodies against heat-killed $A$. actinomycetemcomitans and the culture supernate levels of IFN- $\gamma$ were determined after 1 week. The primary lesion in all groups of mice was induced as described above.

\section{Statistical analysis}

The results were analysed by one-way analysis of variance, followed by the Fisher's least square differences with a statistical software package (Minitab, State College, PA, USA).

\section{Results}

\section{DTH response}

Footpad swelling in mice in group II was significantly greater than that in group I ( $\mathrm{p}<0.05)$. Footpad swelling in group III was smaller than that in group II $(\mathrm{p}<0.05)$, but still greater than that in group I (Table 1).

\section{Serum antibodies}

The levels of serum $\operatorname{IgG}$ and $\operatorname{IgM}$ antibodies against heat-killed $A$. actinomycetemcomitans were significantly higher in group II mice than those in group I $(\mathrm{p}<0.05)$ (Table 1). Similar to the DTH response, the levels of serum $\operatorname{IgG}$ and $\operatorname{IgM}$ anti-A. actinomycetemcomitans antibodies in group III were lower than those in group II $(p<0.05)$, but still higher than those in group I $(\mathrm{p}<0.05)$.

Table 1. Footpad swelling and serum anti-A. actinomycetemcomitans antibodies in carrageenan-untreated and treated mice

\begin{tabular}{cccc}
\hline & & $\begin{array}{c}\text { Footpad } \\
\text { swelling }-\end{array}$ & \multicolumn{2}{c}{$\begin{array}{c}\text { Serum anti-A. actinomycetemcomitans } \\
\text { antibodies }- \text { mean }\end{array}$} \\
\cline { 3 - 4 } Group $^{*}$ & mean (SD) $\mathrm{mm}$ & IgG & IgM \\
\hline I & $0.08(0.01)$ & $3.25(0.16)$ & $4.09(1.21)$ \\
II & $0.68(0.17)$ & $86.57(4.69)$ & $73.64(7.41)$ \\
III & $0.25(0.06)$ & $49.73(3.81)$ & $45.34(3.62)$ \\
\hline
\end{tabular}

* Group I, carrageenan-untreated sham-immunised mice; group II, carrageenan-untreated antigen-immunised mice; group III, carrageenan-treated antigen-immunised mice. 


\section{Culture supernate levels of IFN- $\gamma$}

At $0.1 \mu \mathrm{g}$ of antigen, only cells in group II produced detectable IFN- $\gamma(\mathrm{p}<0.05)$. Spleen cells of all animals produced IFN $-\gamma$ when stimulated with $1 \mu \mathrm{g}$ or $10 \mu \mathrm{g}$ of antigen (Fig. 1). However, the levels of IFN- $\gamma$ released by cells of group II mice were significantly higher than those released by cells of group I and group III $(p<0.05)$. Partial inhibition of IFN- $\gamma$ production by cells of group III was observed, as the levels of IFN- $\gamma$ in this group were lower than those of group II $(p<0.05)$, but still significantly higher than those of group I $(\mathrm{p}<0.05)$.

\section{Primary lesions}

The diameter of abscesses of mice in group I peaked at day 5 after challenge and remained relatively high up to day 30 (Fig. 2). Similarly, the lesions in group II mice peaked at day 5 , but decreased significantly up to day 25 and were healed by day $30(\mathrm{p}<0.05)$. The lesions in group III animals were present up to day 30 and larger than those in group II mice $(p<0.05)$, and smaller than those in group I mice at days 25 and 30 $(\mathrm{p}<0.05)$ (Fig. 2).

\section{Adoptive transfer}

As expected, no footpad swelling was observed in mice in group A. Footpad swelling in group $\mathrm{C}$ mice was significantly greater than that in mice in group B $(\mathrm{p}<0.05)$, indicating that the DTH response in group $\mathrm{C}$ may be mediated by donor-derived DTH effector cells (Table 2). When cells from sham-immunised donor animals were transferred to carrageenan-treated recip-

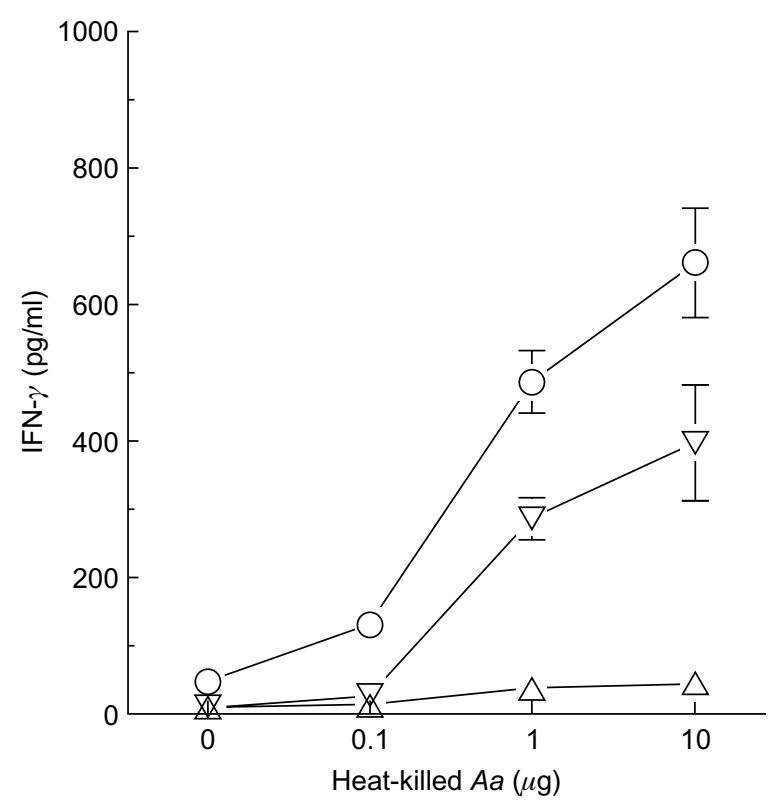

Fig. 1. IFN- $\gamma$ levels detected in the culture supernates in the presence of various concentrations of heat-killed A. actinomycetemcomitans ( $\mathrm{Aa}$ ) for 4 days. Group I, carrageenan-untreated sham-immunised mice $(\triangle)$; group II, carrageenan-untreated antigen-immunised mice $(O)$; group III, carrageenan-treated antigen-immunised mice $(\nabla)$.

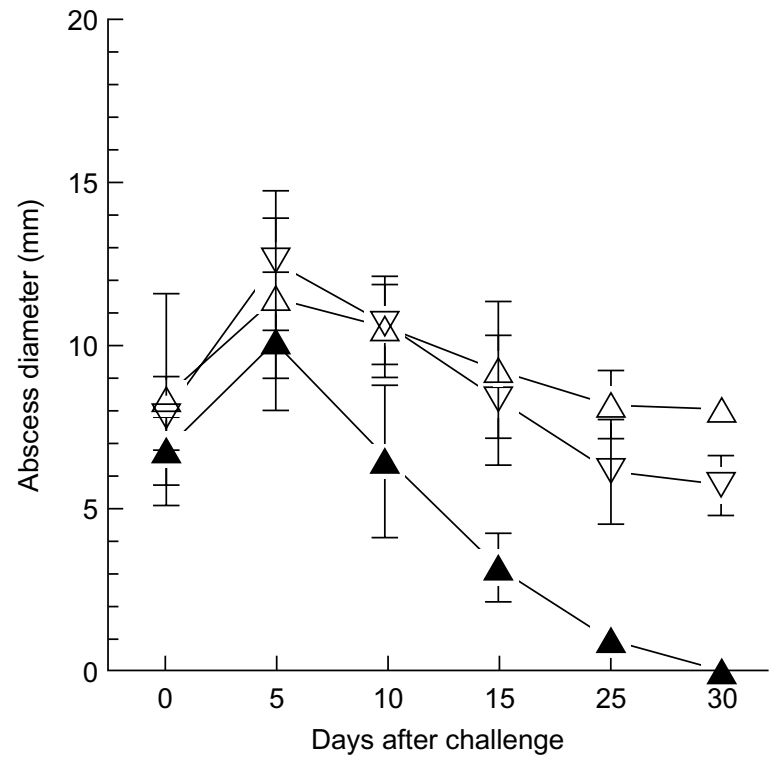

Fig. 2. Abscess diameter at 5-day intervals after inoculation of A. actinomycetemcomitans into mice in each group. Group I, carrageenan-untreated sham-immunised mice $(\triangle)$; group II, carrageenan-untreated antigen-immunised mice $(\mathbf{\Delta})$; group III, carrageenan-treated antigen-immunised mice $(\nabla)$.

Table 2. Footpad swelling and serum anti-A. actinomycetemcomitans antibodies in carrageenan-untreated and treated mice after cell transfer

\begin{tabular}{|c|c|c|c|}
\hline \multirow[b]{2}{*}{ Group } & \multirow{2}{*}{$\begin{array}{c}\text { Footpad } \\
\text { swelling - } \\
\text { mean (SD) mm }\end{array}$} & \multicolumn{2}{|c|}{$\begin{array}{l}\text { Serum anti- } A \text {. actinomycetemcomitans } \\
\text { antibodies - mean (SD) ELISA units }\end{array}$} \\
\hline & & IgG & $\operatorname{IgM}$ \\
\hline A & $0.03(0.00)$ & $2.99(0.04)$ & $2.45(1.21)$ \\
\hline B & $0.16(0.07)$ & $20.57(2.31)$ & $18.69(2.71)$ \\
\hline $\mathrm{C}$ & $0.73(0.13)$ & $91.32(2.74)$ & $72.67(3.28)$ \\
\hline $\mathrm{D}$ & $0.17(0.09)$ & $24.42(2.96)$ & 17.23 (1.09) \\
\hline $\mathrm{E}$ & $0.76(0.15)$ & $87.78(5.40)$ & $68.34(2.11)$ \\
\hline $\mathrm{F}$ & $0.49(0.07)$ & $52.61(8.53)$ & $40.62(5.26)$ \\
\hline G & $0.20(0.04)$ & $28.19(2.81)$ & $20.30(2.59)$ \\
\hline
\end{tabular}

ients (group D), no significant difference between footpad swelling in animals in groups B and D was observed $(p>0.05)$. Footpad swelling in group E was not significantly different to that in group $\mathrm{C}(\mathrm{p}>0.05)$. To further clarify whether macrophages played a role in the increased DTH response seen in group E, these accessory cells isolated from antigen-immunised donors were adoptively transferred to the carrageenantreated recipients (group F). The results showed that footpad swelling in this group of animals was higher than that in groups B and D $(\mathrm{p}<0.05)$, but lower than that in groups $C$ and $E(p<0.05)$. Macrophages from sham-immunised mice failed to transfer DTH response in carrageenan-treated recipients (group G) as compared with that in groups B and D $(p<0.05)$. These results indicated that antigen-activated macrophages may be only partially responsible for the DTH response to $A$. actinomycetemcomitans.

The levels of serum IgG and IgM anti- $A$. actinomycetemcomitans antibodies in animals in groups 
$\mathrm{C}$ and $\mathrm{E}$ were higher than those in groups $\mathrm{A}, \mathrm{B}$ and $\mathrm{D}$ $(p<0.05)$ (Table 2). There was no significant difference between the levels of $\operatorname{IgG}$ and IgM antibodies in group $\mathrm{B}$ and those in group $\mathrm{D}(\mathrm{p}>0.05)$. Serum anti- $A$. actinomycetemcomitans antibody classes in group $\mathrm{F}$ were elevated when compared with those in groups $\mathrm{B}$ and $\mathrm{D}(\mathrm{p}<0.05)$ but were significantly lower than those in groups $\mathrm{C}$ and $\mathrm{E}(\mathrm{p}<0.05)$. Serum antibodies in group $\mathrm{G}$ were significantly lower than those in groups $\mathrm{C}, \mathrm{E}$ and $\mathrm{F}(\mathrm{p}<0.05)$ but were similar to those in groups $\mathrm{B}$ and $\mathrm{D}(\mathrm{p}<0.05)$.

IFN- $\gamma$ plays a crucial role in the DTH response [29]. Therefore, experiments were done to determine the levels of IFN- $\gamma$ produced by spleen cells of all recipient animals. IFN- $\gamma$ was produced by cells from all animals except for group A when stimulated with $1 \mu \mathrm{g}$ of heat-killed A. actinomycetemcomitans (Fig. 3). There was no significant difference between IFN- $\gamma$ production in groups B and D $(\mathrm{p}<0.05)$. The levels of IFN- $\gamma$ in groups $\mathrm{C}$ and $\mathrm{E}$ were significantly higher than those in groups $B, D$ and $G$ when stimulated with either $1 \mu \mathrm{g}$ or $10 \mu \mathrm{g}$ of antigen $(\mathrm{p}<0.05)$. Increased IFN- $\gamma$ production, after stimulation with $10 \mu \mathrm{g}$ of antigen, was detected in group $\mathrm{F}$ as compared with groups $\mathrm{B}$ and $\mathrm{D}(\mathrm{p}<0.05)$, although it was lower than that in groups $\mathrm{D}$ and $\mathrm{E}(\mathrm{p}<0.05)$. It is of interest that mice in group $\mathrm{G}$, which received macrophages from sham-immunised donors, produced levels of IFN- $\gamma$ higher than those seen in groups B and D $(\mathrm{p}>0.05)$ but lower than those in groups $\mathrm{C}, \mathrm{E}$ and $\mathrm{F}(\mathrm{p}<0.05)$.

The abscess lesions in group A mice remained large up to day 30, but those in group B mice were smaller than those in group A mice $(p<0.05)$ (Fig. 4). The lesions

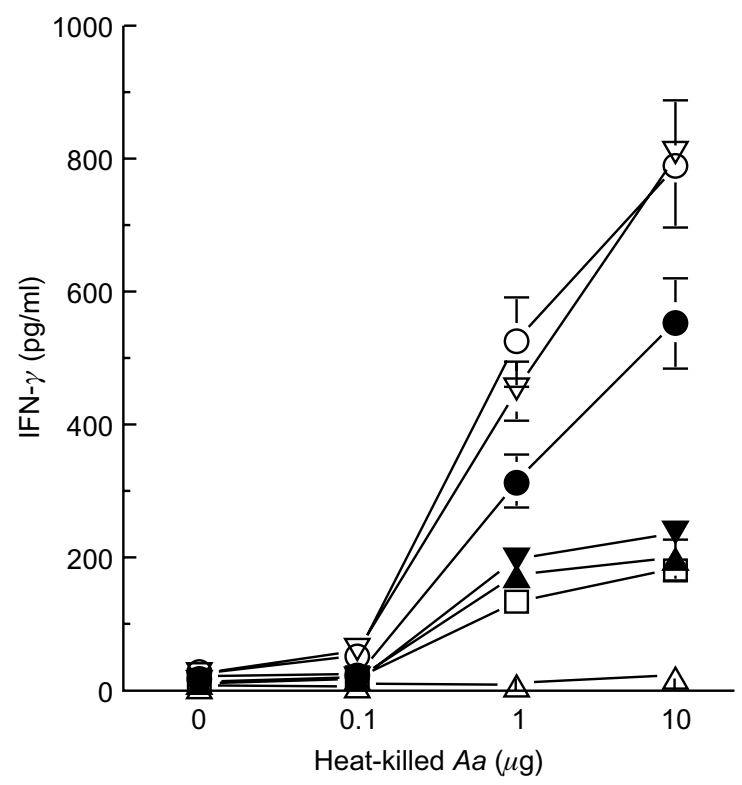

Fig. 3. IFN- $\gamma$ levels detected in the culture supernates in the presence of various concentrations of heat-killed A. actinomycetemcomitans $(\mathrm{Aa})$ for 4 days. (See text for details of the adoptive transfer of mice in groups A-G.) Group A, $\triangle ; \mathrm{B}, \boldsymbol{\Delta}$; $\mathrm{C}, \nabla ; \mathrm{D}, \mathbf{\nabla} ; \mathrm{E}, \mathrm{O} ; \mathrm{F}, \mathbf{O} ; \mathrm{G}, \square$.

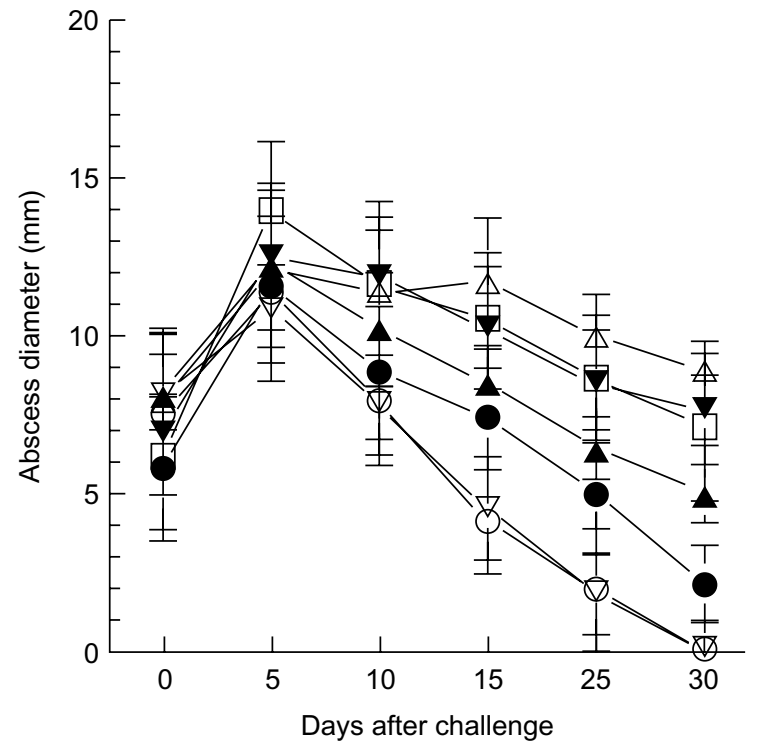

Fig. 4. Abscess diameter at 5-day intervals after inoculation of A. actinomycetemcomitans into mice in each group. (See text for details of the adoptive transfer of mice in groups A-G.) Group A, $\triangle$; B, $\mathbf{\Lambda} ; \mathrm{C}, \nabla ; \mathrm{D}, \mathbf{\nabla} ; \mathrm{E}, \mathrm{O} ; \mathrm{F}, \mathbf{0} ; \mathrm{G}, \square$.

in group C mice, but not group A and group B, were completely healed at day $30(\mathrm{p}<0.05)$. When carrageenan-treated mice of group D were given spleen cells from sham-immunised mice and abscess formation was induced, the diameter of the lesions in this group remained high up to day 30 and was not significantly different from those in group A mice $(p>0.05)$. As with group $\mathrm{C}$ mice, the lesions in group $\mathrm{E}$ healed at day 30 ( $p>0.05)$. Interestingly, when the carrageenantreated recipients (group F) had received macrophages from antigen-immunised mice, the lesion diameters were still higher than in groups $\mathrm{C}$ and $\mathrm{E}(\mathrm{p}<0.05)$, but lower than in groups $\mathrm{A}, \mathrm{B}$ and $\mathrm{D}(\mathrm{p}<0.05)$. On the other hand, in the carrageenan-treated recipients (group G) given macrophages from sham-immunised mice, the diameter of the lesions was not significantly different from those in group A and D mice $(\mathrm{p}>0.05)$.

\section{Discussion}

The results of the present study have shown that, after immunisation with heat-killed $A$. actinomycetemcomitans, footpad swelling of carrageenan-treated mice was greater than that in the sham-immunised mice, but lower than that in antigen-immunised mice. This observation indicates that carrageenan causes partial suppression of the DTH response to A. actinomycetemcomitans. A previous study suggested that carrageenan injections inhibit antigen presentation but not phagocytic functions of macrophages in vivo [21]. Therefore, the partial suppression of the DTH response to $A$. actinomycetemcomitans in carrageenan-treated mice observed in the present study indicates that macrophages may not be the sole APCs for the DTH response induced by this potential periodontal pathogen in mice. Along with macrophages, dendritic cells are 
known to efficiently process and present antigens to $T$ cells in the induction of the DTH response as seen in contact sensitivity $[30,31]$ and intracellular bacteriainduced cellular immunity [32]. Injection of carrageenan to block macrophage functions is well reported [20-24], but whether or not dendritic cells would be eliminated by such treatment is still unknown. Thus, it can be assumed that not only macrophages but also dendritic cells may act as APCs in the induction of the DTH response to A. actinomycetemcomitans seen in the present study. Indirect support for this proposition can be drawn from the fact that oral bacteria, such as $P$. gingivalis, activate gingival dendritic cells which in turn might present antigens to $\mathrm{T}$ cells [33]. Indeed, a study by Gong et al. has shown that antigen presentation by both murine macrophages and dendritic cells stimulates higher levels of antigen-specific T-cell proliferation than that by only one of these APCs [34]. Alternatively, the partial DTH suppression induced by A. actinomycetemcomitans seen in the present study may be mediated by carrageenan-enhanced $\mathrm{CD}^{+} \mathrm{T}-$ cell activities or decreased T-cell migration, or both, as observed previously [21, 35].

In carrageenan-treated mice, the levels of serum IgG and IgM anti-A. actinomycetemcomitans antibodies were suppressed as compared with those in antigenimmunised mice, but were up-regulated as compared with those in sham-immunised mice. These results indicated that carrageenan-induced macrophage inhibition led to partially down-regulated anti-A. actinomycetemcomitans IgG and IgM antibody production. Compatible results have also been reported by Taubman et al., who showed that depletion of macrophages from gingival mononuclear cells of patients with periodontal disease resulted in reduction of antibody production by $70-73 \%$ [19]. However, the partial suppression of serum IgG and IgM anti-A. actinomycetemcomitans antibodies after carrageenan treatment seen in the present study suggests that macrophages may only be one of the APCs orchestrating the induction of immune response to this periodontopathogen. There is evidence that both dendritic and B cells can also act as APC for T-cell activation, which in turn provides signals, such as cytokines, necessary for further B-cell differentiation [36]. Although solid evidence showing the ability of $\mathrm{B}$ cells to present $A$. actinomycetemcomitans has not yet been documented, the antibody production seen in the carrageenan-treated mice might be due to the antigen presentation functions of $B$ cells and needs to be investigated further. Alternatively, in the absence of macrophages due to carrageenan treatments, dendritic cells may be the only APCs to regulate $\mathrm{B}-c e l l$ activation and anti- $A$. actinomycetemcomitans antibody production. It is also possible that the partial suppression of anti-A. actinomycetemcomitans antibody production in carrageenaninduced macrophage inhibition may be the result of increased $\mathrm{CD}^{+}$T-cell activation or reduced T-cell migration, or both $[21,35]$.
As IFN- $\gamma$ produced by $\mathrm{T}$ cells plays a crucial role in the induction of DTH response to A. actinomycetemcomitans in mice [37], it was also worth determining whether the partial inhibition of DTH response in carrageenan-treated mice was paralleled by alteration of IFN- $\gamma$ profiles. The results showed that the levels of IFN- $\gamma$ in the spleen cell cultures of carrageenan-treated mice were lower than those in the antigen-immunised mice but higher than in the sham-immunised mice, suggesting that carrageenan-induced macrophage inhibition led to the partial suppression of the production of IFN- $\gamma$, which coincided with partial down-regulation of DTH response. These results are consistent in that this cytokine is pivotal in the development of a Th1 cell population, which in turn promotes DTH response [29]. Thus, the simplest explanation of the results seen in the present study is that carrageenan-induced macrophage inhibition may lead to reduce Th1 development, thereby decreasing IFN- $\gamma$ production. Alternatively, reduced IFN- $\gamma$ levels in the A. actinomycetemcomitans-stimulated spleen cells of carrageenan-treated mice might be produced by CD4 cells after this T-cell subset only interacted with antigen-activated dendritic cells, but not with both macrophages and dendritic cells, as seen in a previous study [34].

The size of abscesses in the carrageenan-treated mice was smaller than in the negative control but greater than in the positive control, indicating that the lesions in group III could only partially be resolved. In a previous study it was shown that increased murine immune response to A. actinomycetemcomitans-derived surface-associated material is associated with rapid healing of the lesions induced by this periodontopathogen [38]. Thus, it seems plausible that inhibition of macrophage function by the carrageenan treatments may lead to partial suppression of production of antibody $A$. actinomycetemcomitans, leading to failure to completely resolve the lesions induced by this periodontopathogen.

To verify that the partial suppression of murine immune response to $A$. actinomycetemcomitans was due to carrageenan-induced macrophage inhibition as seen in the present study, either spleen cells or macrophages from the immunised mice were transferred to carrageenan-treated recipients. The results showed that adoptive transfer of antigen-immunised spleen cells fully restored the immune responses to $A$. actinomycetemcomitans in the carrageenan-treated recipients, as judged by enhanced DTH response, levels of IFN- $\gamma$ in supernates and serum IgG and IgM anti- $A$. actinomycetemcomitans antibody levels. Transfer of invivo antigen-pulsed macrophages led to only partial recovery of the immune response to this periodontopathogenic bacterium in the carrageenan-treated recipients. In sharp contrast, macrophages from shamimmunised donors transferred to the carrageenantreated recipients resulted only in the induction of an immune response similar to that of the recipients of 
sham-immunised spleen cells. Macrophages from sham-immunised donors might process antigens for the first time in carrageenan-treated recipients and subsequently present them to $\mathrm{T}$ cells, thereby developing a primary immune response in the carrageenan-treated recipients. On the other hand, although macrophages pulsed with antigen in vivo did elevate the immune response in the carrageenan-treated recipients, they failed to fully restore the immune response in the recipients. Indeed, while adoptive transfer of antigenimmunised spleen cells to carrageenan-treated mice led to a complete healing of the lesions induced by this periodontopathogen at day 30 , the lesions remained detectable up to day 30 in the carrageenan-treated recipients of macrophages from antigen-immunised mice. These results indicate that macrophages alone could not induce the immune response and elimination of the lesions induced by A. actinomycetemcomitans, confirming that these accessory cells may be only part of the APC network in the induction of the immune response to A. actinomycetemcomitans in mice. Support can be drawn from the fact that in the mouse spleen, dendritic cells, but not macrophages, are the primary APCs which present protein antigens to T cells [34]. Further studies to delineate the co-operation of macrophages and other types of APCs, such as dendritic cells, in the induction of the immune response to $A$. actinomycetemcomitans are needed.

The extrapolation of the present study to the immunopathogenesis of periodontal disease remains speculative. It has been shown that MHC class II-bearing APCs in the gingiva of patients with periodontal disease are increased and these include macrophages, dendritic cells and keratinocytes, indicating heterogeneity of APC types for T-cell activation in gingival diseased sites $[17,18]$. Indeed, human gingival Langerhans cells may induce allogeneic lymphocyte proliferation in an MHC class II molecule-dependent fashion [39]. Therefore, the results of the present study support the view that antigen-presentation functions of gingival macrophages may be part of the entire gingival APC network which processes and presents antigens of periodontopathogens to $\mathrm{T}$ cells.

We are grateful to Professor Greg Seymour and Dr Philip S. Bird (University of Queensland, Brisbane, Australia) for providing the oral bacteria. The technical assistance of Mrs Eka is acknowledged. This work was partly supported by RUT III (to W.S., while employed by GMU) and Risbin Iptekdok (to E.H.) from the Ministry of Research and Technology, the Indonesian government.

\section{References}

1. Wilson M, Henderson B. Virulence factors of Actinobacillus actinomycetemcomitans relevant to the pathogenesis of inflammatory periodontal diseases. FEMS Microbiol Rev 1995; 17: $365-379$.

2. Meyer DH, Fives-Taylor PM. The role of Actinobacillus actinomycetemcomitans in the pathogenesis of periodontal disease. Trends Microbiol 1997; 5: 224-228.

3. Ebersole JL, Cappelli D, Sandoval M-N. Subgingival distribution of $A$. actinomycetemcomitans in periodontitis. $J$ Clin
Periodontol 1994; 21: 65-75.

4. Müller H-P, Heinecke A, Borneff M, Knopf A, Klencke C, Pohl S. Microbial ecology of Actinobacillus actinomycetemcomitans, Eikenella corrodens and Capnocytophaga spp., in adult periodontitis. J Periodont Res 1997; 32: 530-542.

5. van Winkelhoff AJ, de Groot P, Abbas F, de Graaf J Quantitative aspects of the subgingival distribution of Actinobacillus actinomycetemcomitans in a patient with localized juvenile periodontitis. J Clin Periodontol 1994; 21: 199-202.

6. Zambon JJ, Haraszthy VI, Hariharan G, Lally ET, Demuth DR. The microbiology of early-onset periodontitis: association of highly toxic Actinobacillus actinomycetemcomitans strains with localized juvenile periodontitis. J Periodontol 1996; 67: 282-290.

7. Agarwal S, Piesco NP, John LP, Riccelli AE. Differential expression of IL- $\beta$, TNF- $\alpha$, IL- 6 and IL- 8 in human monocytes in response to lipopolysaccharides from different microbes. $J$ Dent Res 1995; 74: 1057-1065.

8. Yoshimura A, Hara Y, Kaneko T, Kato I. Secretion of IL-1 $\beta$, TNF- $\alpha$, IL- 8 and IL-1ra by human polymorphonuclear leukocytes in response to lipopolysaccharides from periodontic bacteria. J Periodont Res 1997; 32: 279-286.

9. Teng Y-TA, Nguyen H, Gao X et al. Functional human T-cell immunity and osteoprotegerin ligand control alveolar bone destruction in periodontal infection. J Clin Invest 2000; 106: R59-R67.

10. Muro M, Koseki T, Akifusa S et al. Role of CD14 molecules in internalization of Actinobacillus actinomycetemcomitans by macrophages and subsequent induction of apoptosis. Infect Immun 1997; 65: 1147-1151.

11. Kato S, Nakashima K, Inoue $\mathrm{M}$ et al. Human epithelial cell death caused by Actinobacillus actinomycetemcomitans infection. J Med Microbiol 2000; 49: 739-745.

12. Hillmann G, Dogan S, Geurtsen W. Histopathological investigation of gingival tissue from patients with rapidly progressive periodontitis. J Periodontol 1998; 69: 195-208.

13. Sosroseno W, Herminajeng E, Herwiyanti S, Ghufron M. Effects of cytokines on Porphyromonas gingivalis-induced opsonophagocytosis of a murine macrophage cell line. Eur $J$ Sci 2000; 108: 561-563.

14. Sosroseno W, Herminajeng E. The immunopathology of chronic inflammatory periodontal disease. FEMS Immunol Med Microbiol 1995; 10: 171-180.

15. Gemmell E, Marshall RI, Seymour GJ. Cytokines and prostaglandins in immune homeostatis and tissue destruction in periodontal disease. Periodontol 2000 1997; 14: 112-143.

16. Daniel MA, Van Dyke TE. Alterations in phagocyte function and periodontal infection. J Periodontol 1996; 67 (10 Suppl): 1070-1075.

17. Seymour GJ, Gemmell E, Walsh LJ, Powell RN. Immunohistological analysis of experimental gingivitis in humans. Clin Exp Immunol 1988; 71: 132-137.

18. Walsh LJ, Armitt KL, Seymour GJ, Powell RN. The immunohistology of chronic gingivitis in children. Pediatric Dent 1987; 9: 26-32.

19. Taubman MA, Stoufi ED, Seymour GJ, Smith DJ, Ebersole JL. Immunoregulatory aspects of periodontal disease. Adv Dent Res 1988; 2: 328-333.

20. Ishizaka S, Kuriyama $\mathrm{S}$, Tsujii $\mathrm{T}$. In vivo depletion of macrophages by desulfated $\iota$-carrageenan in mice. J Immunol Methods 1989; 124: 17-24

21. Vijayakumar RK, Palaniel V, Muthukkaruppan VR. Influence of carrageenan on peritoneal macrophages. Immunol Lett 1989/ 1990; 23: 55-60.

22. Vijayakumar RK, Muthukkaruppan VR. Immunoregulatory processes induced by carrageenan in $\mathrm{BALB} / \mathrm{C}$ mice. Immunol Invest 1990; 19: 163-183.

23. Tachibana T, Matsuyama T, Mitsuyama M. Involvement of $\mathrm{CD} 4+\mathrm{T}$ cells and macrophages in acquired protection against infection with Sporothrix schenckii in mice. Med Mycol 1999; 37: $397-404$.

24. Böhm W, Schirmbeck R, Elbe A et al. Exogenous hepatitis B surface antigen particles processed by dendritic cells or macrophages prime murine MHC class I-restricted cytotoxic $\mathrm{T}$ lymphocytes in vivo. J Immunol 1995; 155: 3313-3321.

25. Yamaguchi N, Yamashita Y, Ikeda D, Koga T. Actinobacillus actinomycetemcomitans serotype b-specific polysaccharide antigen stimulates production of chemotactic factors and inflammatory cytokines by human monocytes. Infect Immun 1996; 
64: $2563-2570$.

26. Ogata M, Matsui T, Kita T, Shigematsu A. Carrageenan primes leukocytes to enhance lipopolysaccharide-induced tumor necrosis factor alpha production. Infect Immun 1999; 67: 3284-3289.

27. Herminajeng E, Sosroseno W, Bird PS, Seymour GJ. The effects of interleukin-10 depletion in vivo on the immune response to Porphyromonas gingivalis in a murine model. J Periodontol 2001; 72: 1527-1534.

28. Bird PS, Gemmell E, Polak B, Paton RG, Sosroseno W, Seymour GJ. Protective immunity to Porphyromonas gingivalis infection in a murine model. J Periodontol 1995; 66: 351-362.

29. O'Garra A. Cytokines induce the development of functionally heterogenous $\mathrm{T}$ helper cell subsets. Immunity 1998; 8: $275-283$.

30. Sosroseno W. The immunology of nickel-induced allergic contact dermatitis. Asian Pac J Allergy Immunol 1995; 13 $173-181$.

31. Grabbe S, Schwarz T. Immunoregulatory mechanisms involved in elicitation of allergic contact hypersensitivity. Immunol Today 1998; 19: 37-44.

32. Demangel $\mathrm{C}$, Britton WJ. Interaction of dendritic cells with mycobacteria: where the action starts. Immunol Cell Biol 2000; 78: $318-324$.

33. Cultler CW, Jotwani R, Palucka KA, Davoust J, Bell D,
Banchereau J. Evidence and a novel hypothesis for the role of dendritic cells and Porphyromonas gingivalis in adult periodontitis. J Periodont Res 1999; 34: 406-412.

34. Gong JL, McCarthy KM, Rogers RA, Schneeberger EE. Interstitial lung macrophages interact with dendritic cells to present antigenic peptides derived from particulate antigens to T cells. Immunology 1994; 81: 343-351.

35. Yamada S, Ishii M, Kisara N, Nagatomi R, Toyota $T$. Macrophages are essential for lymphocyte infiltration in formyl peptide-induced cholangitis in rat liver. Liver 1999; 19: $253-258$.

36. MacPherson G, Kushnir N, Wykes M. Dendritic cells, B cells and the regulation of antibody synthesis. Immunol Rev 1999; 172: $325-334$.

37. Takahashi I, Nakagawa I, Xu L, Hamada S. Role of $\alpha \beta$ T cells and $\gamma \delta \mathrm{T}$ cells in protective immunity to Actinobacillus actinomycetemcomitans in mutant mice by targeted gene disruption. J Periodont Res 1996; 31: 589-595.

38. Herminajeng E, Asmara W, Yuswanto A, Barid I, Sosroseno W. Protective humoral immunity induced by surface-associated material from Actinobacillus actinomycetemcomitans in mice. Microbes Infect 2001; 3: 997-1003.

39. Walsh LJ, Seymour GJ, Powell RN. Human gingival Langerhans cells stimulate allogeneic lymphocytes: requirement for MHC class II antigens. J Periodontol 1990; 61: 328-333. 